Ann. Zootech., 1984, 33 (1), 33-50

\title{
Effect of restricted feeding and realimentation on compensatory growth, carcass composition and organ growth in rabbit
}

\author{
Inger LEDIN \\ Department of Animal Husbandry \\ Swedish University of Agricultural Sciences \\ S-750 07 Uppsala, Suède
}

\begin{abstract}
Summary
The effect of restricted feeding and realimentation on growth and carcass composition was studied in two experiments, each using 30 rabbits of the Swedish White Domestic Breed. The rabbits were slaughtered in groups of 5. The restricted feeding started at 1.0 or $1.6 \mathrm{~kg}$ live weight respectively, restriction lasting to 2.1 or $2.4 \mathrm{~kg}$. The highest slaughter weight was $3.2 \mathrm{~kg}$. The feed restriction was to $60 \mathrm{p}$. 100 of the ad libitum consumption of the litter mates at the same age or same weight and realimentation ad libitum or 100 p. 100 respectively. The nutritive value of the pelleted diet was determined in digestibility trials and carcass composition was studied by mincing and chemical analysis of soft tissue.

Restricted feeding produced carcasses which, at the same weight, had a lower content of fat, a higher content of protein and the same content of water in the soft tissue. After realimentation, the carcasses had still a lower content of fat, the same content of protein and a higher content of water. There was a tendency to a higher feed consumption at $a d$ libitum feeding during realimentation compared with continuous ad libitum feeding. The restriction had a significant effect on digestibility, which was better in the restricted animals, especially in expt. 1.

The treatments had no effect on total feed consumption, total feed efficiency or protein retention. There was a tendency to better growth rates during realimentation and in expt. 2 also a tendency to a better daily carcass weight gain. However, the differences were not significant.

Of the internal organs, weight of liver was the most affected by restriction and realimentation.
\end{abstract}

Key words : Rabbit, feed restriction, realimentation, compensatory growth, carcass composition.

\section{Introduction}

Compensatory growth is the rapid growth, relative to age, that occurs after a period of growth retardation, when a restriction in feed allowance is removed (WILSON \& OsBouRn, 1960). Compensatory growth is of general interest for the understand- 
ing of growth. It is also a significant problem in animal production in many parts of the world where seasonal and climatic fluctuations result in drastic changes in feed availability and thus in growth rate of animals (REID \& WHITE, 1977).

Production systems, in which a low plane of nutrition is applied during the indoor feeding period followed by a high feeding level on pasture, can be of economic interest. Compensatory growth has therefore been studied thoroughly in grazing animals. On the other hand experiments on monogastrics such as pigs and poultry have usually aimed at studying the possibility of changing carcass composition by introducing alternative feeding levels.

Compensatory growth after a period of undernutrition is a very constant feature in higher animals (WILSON \& OSBOURN, 1960). It has been found in horses (ELLIS \& Lawrence, 1978 a), rats (Meyer \& Clawson, 1964 ; Liljedahl \& Neimann-SorenSEN, 1968 ; Harris \& Widdowson, 1978) and also in poultry (Auckland, Morris \& Jennings, 1969 ; Deaton et al., 1973 ; Pokniak \& CoRnejo, 1982). In pigs severe undernutrition early in life resulted in the realimentation period in slower growth or, at best in the same rate as the controls (MCMEeKan, 1940; Lister \& MCCANCE, 1967 ; Allee \& Noll, 1980). Pigs that were restricted later in life showed some compensatory growth (LIEBERT et al., 1981).

When given feed ad libitum after feed restriction, monogastrics often show an increase in feed consumption, in comparison with continuously ad libitum fed animals in the same weight range (Auckland, Morris \& Jennings, 1969 ; Aucki.and \& MorRIS, 1971 ; Ellis \& LaWrence, 1978 b). However, this could not be confirmed by MEYER \& ClaWSON (1964).

Severe undernutrition followed by realimentation resulted in rapid deposition of fat in rats (MEYER \& Clawson, 1964 ; HARRIS \& WidDowson, 1978) and in pigs (McMeekan, 1940 ; Lister \& MCCance, 1967). Liebert et al., 1981) found that a mild restriction resulted in pig carcasses with a higher protein and lower fat content than controls. In poultry, AUCKLAND \& Morkis (1971) found no difference between control and realimented animals whereas PoKNIAK \& CoRneJo (1982) showed that realimented animals were fatter. In rabbits a low protein diet reduced the growth rate but had no effeat on carcass composition (Ouhayoun, Delmas \& Lebas, 1979).

The present investigations were carried out to study the effects on rabbits of a mild feed restriction followed by realimentation. Comparison were made with animals fed either continuously ad libitum or continuously restrictive. The effects were measured in growth rate, feed consumption, carcass composition and organ growth.

\section{Material and methods}

\section{A. Experimental animals and design}

Each of the two experiments contained 30 rabbits of the Swedish White Domestic Breed. Expt. 1 comprised 25 males and 5 females; Expt. 2, 12 males and 18 females. In each experiment all the rabbits were sired by one buck and their mothers were 


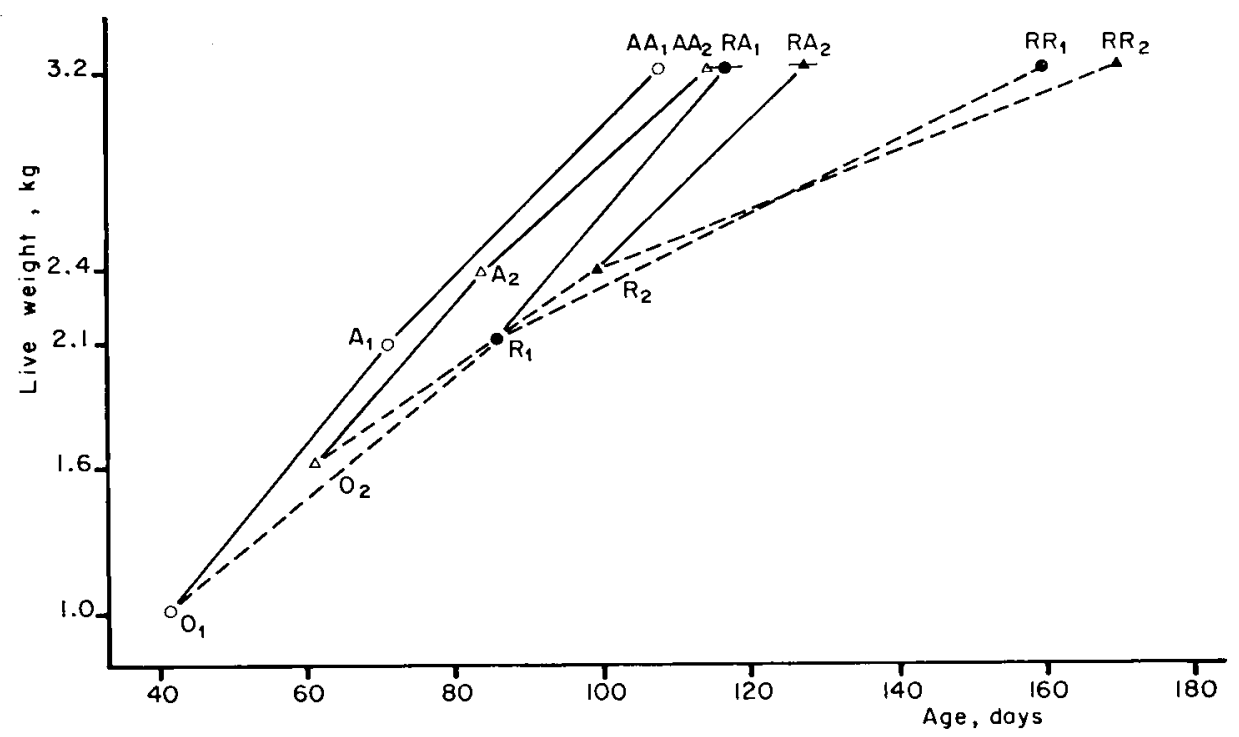

FIG. 1

Experimental design.

Schéna expérimental.

Expt. 1

Period 1: $1000-2100 \mathrm{~g}$.

Period 2 : 2 100-3 $200 \mathrm{~g}$.

- 5 rabbits slaughtered.

5 lapins abattus.

$\mathrm{O}_{1}$ : Slaughtered at start. Abattus au début.

$\mathrm{A}_{1}$ : Fed ad libitum; $1000-2100 \mathrm{~g}$. Nourris ad libitum; $1000-2100 \mathrm{~g}$.

$\mathrm{AA}_{1}$ : Fed ad libitum; $1000-3200 \mathrm{~g}$. Nourris ad libitum; $1000-3200 \mathrm{~g}$.

$\mathrm{R}_{4}$ : Restricted to 60 p. 100 of the average consumption of their litter mates in the groups $A_{1}$ and $\mathbf{A A}_{1}$ at the same age; $1000-2100 \mathrm{~g}$.

Rationnés à $60 \mathrm{p} .100$ de la consommation moyenne des frères et des sæurs de même âge que ceux des groupes $A_{1}$ et $A A_{t} ; 1000-2100 \mathrm{~g}$.

$\mathbf{R R}_{1}$ : Same as $\mathrm{R}_{1} ; 1000-3200 \mathrm{~g}$. Idem $R_{1} ; 1000-3200 \mathrm{~g}$.

$\mathbf{R A}_{1}$ : Same as $\mathbf{R}_{1} ; 1000-2100 \mathrm{~g}$. Idem $R_{1} ; 1000-2100 \mathrm{~g}$.

Ad libitum; $2100-3200 \mathrm{~g}$.

Ad libitum; $2100-3200 \mathrm{~g}$.
Expt. 2

Period 1: $1600-2400 \mathrm{~g}$.

Period $2: 2400-3200 \mathrm{~g}$.

$\triangle 5$ rabbits slaughtered.

5 lapins abattus.

$\mathrm{O}_{2} \quad$ : Slaughtered at start. Abattus au début.

$\mathrm{A}_{2 .} \quad$ : Fed ad libitum; $1600-2400 \mathrm{~g}$. Nourris ad libitum; $1600-2400 \mathrm{~g}$.

$\mathrm{AA}_{2}$ : Fed ad libitum; $1600-3200 \mathrm{~g}$.

Nourris ad libitum; 1600-3200 g.

$\mathrm{R}_{\Delta}$ : Restricted to $60 \mathrm{p} .100$ of the average consumption of their litter mates in groups $\mathrm{A}_{2}$ and $\mathrm{AA}_{\mathrm{*}}$ at the same weight ; $1600-2400 \mathrm{~g}$.

Rationnés à $60 \mathrm{p} .100$ de la consommation moyenne des frères et des saurs de même poids que ceux de groupes $A_{z}$ et $A A_{z} ; 1600-2400 \mathrm{~g}$.

$\mathbf{R R}_{2}$ : Same as $\mathrm{R}_{2} ; 1600-3200 \mathrm{~g}$. Idem $R_{\mathrm{z}} ; 1600-3200 \mathrm{~g}$.

$\mathrm{RA}_{2}$ : Same as $\mathrm{R}_{2} ; 1600-2400 \mathrm{~g}$. 100 p. 100 of the consumption of their litter mate in group $\mathrm{AA}_{2}$ at the same weight : $2400-3200 \mathrm{~g}$.

Idem $R_{8} ; 1600-2400 \mathrm{~g}$.

100 p. 100 de la consommation de frère ou sæur de même poids que celle du groupe $A_{2} ; 2400-3200 \mathrm{~g}$. 
half-sisters or sisters. The same buck and two of the does were used in both experiments. Five does were used to produce 6 young rabbits for each experiment. One rabbit in each of the five litters was randomly allocated to groups $O$ (slaughtered at start), A and AA (fed ad libitum), R and RR (restricted) or RA (restricted realimented). However, regard was taken to sex, so that the groups that were to be compared contained the same number of males and females. The experimental design is shown schematically in fig. 1 and in the text to the figure the treatment periods and slaughter weights in the two experiments are described in detail.

At 17 days of age the litter was partitioned from the doe by wire netting and the young rabbits were given access to water and experimental feed in their part of the cage. The doe was let in for suckling once a day. The young were weaned at 35 days of age and moved to individual cages and the weekly recording of feed consumption and live weight commenced.

The restricted feeding was started when the average weight of the rabbits in the litter reached $1.0 \mathrm{~kg}$ in Expt. 1 and $1.6 \mathrm{~kg}$ in Expt. 2. The rabbits were fed twice daily. The feed of the restricted rabbits was weighed in daily portions. The first experiment showed that live weight was not a very good predictor of carcass weight. In Expt. 2 the rabbits were fasted for 16 hours before each weighing and slaughter in order to reduce that part of the variation in dressing percentage caused by differing gut fill. Thus, live weight in Expt. 2 was body weight after 16 hours' fasting (4 p.m. 8 a.m.). Animals in groups R, RR and RA were restricted to 60 p. 100 of the average consumption of their litter mates in groups A and AA. In Expt. 1 the amounts of feed were calculated from the ad libitum feed consumption of their litter mates at the same age. In Expt. 2 the restrictively fed rabbits obtained 60 p. 100 of their litter mates' ad libitum consumption at the same fasted body weight. The patterns of realimentation also differed. In Expt. 1 the realimented rabbits were fed ad libitum, while in Expt. 2 they were fed 100 p. 100 of the consumption of their litter mates at the same fasted body weight.

\section{B. Diets}

The diets were pelleted mixes. Their ingredients and chemical composition are listed in Table 1. A digestibility trial was made with groups $A$ and $R$ in period 1 and AA, RA and RR in period 2. The average weight of each group at the start of the collection period is stated more precisely in Table 2 . The rabbits were placed in the metabolism cages 7 days before the collection of faeces started. The collection period was 7 days. The faeces were dried at $65^{\circ} \mathrm{C}$ for 24 hours. Faeces and feed samples were ground and analysed for energy, DM (dry matter) ash, crude protein, ether extract, NDF (neutral detergent fibre) and ADF (acid detergent fibre).

\section{Slaughter technique and carcass treatment}

The animals were killed by $\mathrm{CO}_{2}$ inhalation. The internal organs were removed and the digestive tract was divided into stomach, small intestine, caecum and colon and weighed both full and empty. The rabbits were flayed, the head removed above the atlas vertebra and the paws at the carpal and tarsal joints. The carcasses were frozen until further treatment. All parts of the digestive tract, liver, kidneys, heart and dressed fat (fat from guts, kidneys, stomach and the fat depots in the groin, the neck and the axillae) were dried at $100{ }^{\circ} \mathrm{C}$ for 4 to 7 days, depending on weight. 


\section{TABLE 1}

Composition of the diets,

expressed as percentage of feed and gross energy content as $M J / k g$ feed.

Composition et analyse chimique des régimes (en pourcentage).

\begin{tabular}{|c|c|c|}
\hline & \multicolumn{2}{|c|}{ Percentage of diet } \\
\hline & $\begin{array}{c}\text { Expt. } 1 \\
\text { Diet } 1\end{array}$ & $\begin{array}{l}\text { Exp. } 2 \\
\text { Diet } 2\end{array}$ \\
\hline \multicolumn{3}{|l|}{ Ingredients } \\
\hline$\ldots \ldots \ldots \ldots$ & 5.0 & 10.0 \\
\hline Wheat bran & 12.0 & 30.0 \\
\hline Soybean meal & 5.0 & 1.5 \\
\hline Dried beet pulp & 10.0 & - \\
\hline Dehydr. grass meal $\ldots \ldots \ldots \ldots \ldots \ldots \ldots \ldots \ldots$ & 62.0 & 55.0 \\
\hline Molasses $\ldots \ldots \ldots \ldots \ldots \ldots \ldots \ldots \ldots \ldots \ldots$ & 4.0 & 1.5 \\
\hline Vitamins $\ldots \ldots \ldots \ldots$ & 1.5 & 1.5 \\
\hline $\mathrm{NaCl} \ldots \ldots \ldots \ldots \ldots \ldots \ldots$ & 0,5 & 0.5 \\
\hline \multicolumn{3}{|l|}{ Chemical composition } \\
\hline$\ldots \ldots \ldots \ldots \ldots$ & 90.1 & 91.9 \\
\hline Ash $\ldots \ldots$. & 7.9 & 7.5 \\
\hline Crude protein $\ldots \ldots \ldots \ldots \ldots \ldots \ldots \ldots \ldots \ldots$ & 15.1 & 15.9 \\
\hline Ether extract $\ldots \ldots \ldots \ldots \ldots \ldots \ldots \ldots \ldots \ldots$ & 3.9 & 4.8 \\
\hline 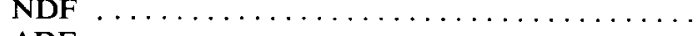 & 33.0 & 31.7 \\
\hline $\mathrm{ADF}^{\prime}, \ldots \ldots \ldots \ldots \ldots \ldots \ldots \ldots \ldots \ldots \ldots \ldots \ldots \ldots \ldots$ & 25.9 & 19.9 \\
\hline Organic matter $\ldots \ldots \ldots \ldots \ldots \ldots$ & 82.2 & 84.4 \\
\hline Gross energy, MJ/kg feed & 16.42 & 17.05 \\
\hline
\end{tabular}

The carcasses were thawed and boiled under pressure for 15 minutes per $\mathrm{kg}$ carcass in order to separate soft tissue from bone. The soft tissue was mixed with water and homogenized. A sample of the mixture was freeze-dried and analysed for DM, ash, crude protein and energy. Ether extract was calculated as the difference between total DM and the sum of ash and protein.

Empty body weight expresses live weight at slaughter minus contents of the digestive tract. Carcass weight was weighed immediately after dissection. The chemical components of the carcass are expressed as percentage of soft tissue (dressed carcass minus bones) and the energy as $\mathrm{MJ} / \mathrm{kg}$ soft tissue.

\section{Analytical methods}

All chemical analyses were carried out according to standard procedures. Ether extract was determined with a two-stage analysis recommended by MATTSSON (1978) and ADF and NDF according to GoERING \& VAN SoEST (1970). Diet 2 had to be treated with amylase to make the NDF method work. Gross energy values for diets, faeces and freeze-dried meat were determined in an adiabatic bomb calorimeter. 


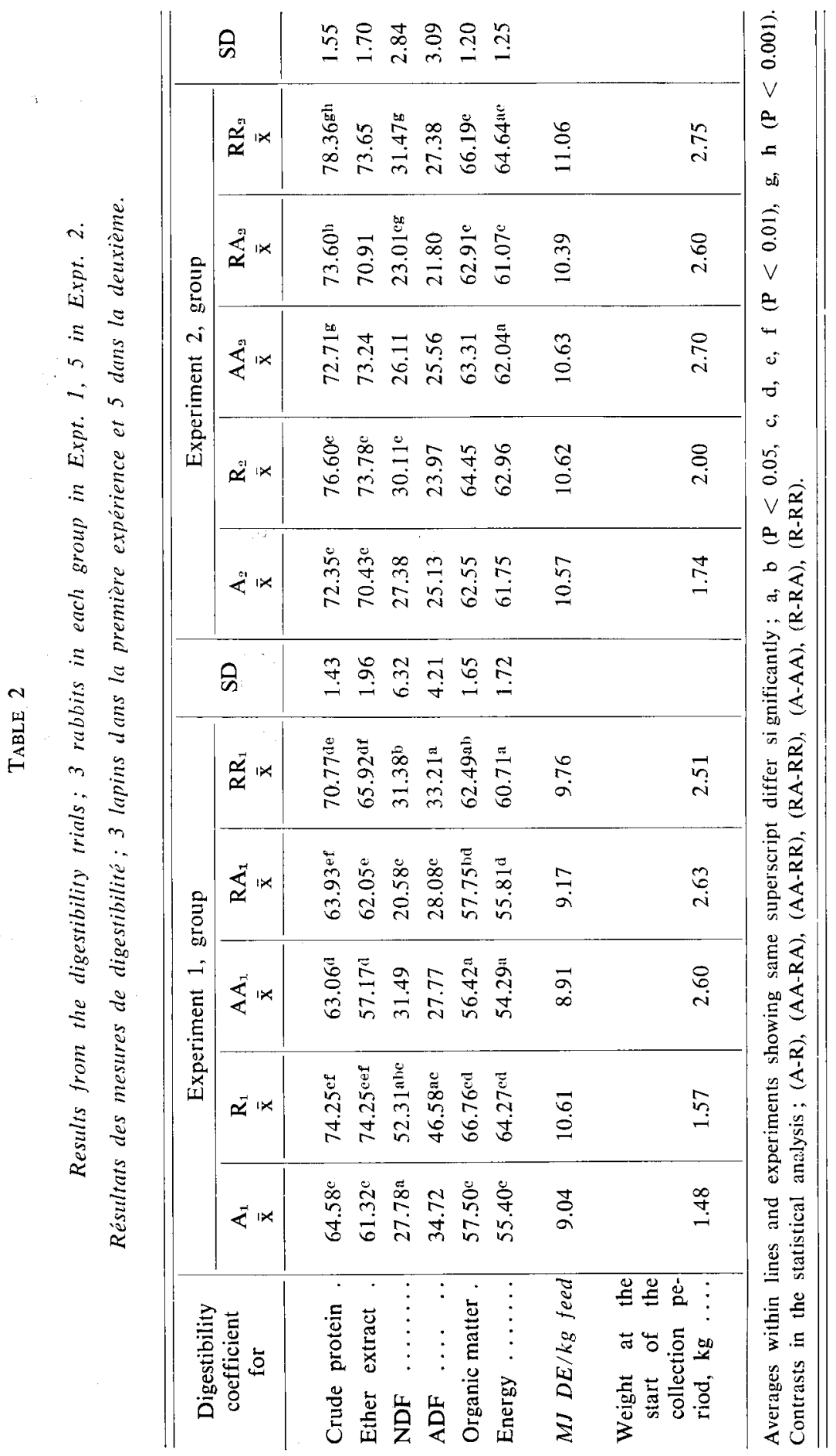




\section{E. Statistical methods}

The data from the experiments were analysed with a variance analysis according to the block model (DUNN \& Clarke, 1974).

$$
Y_{i j}=\ell+\alpha_{i}+\beta_{j}+\alpha \beta_{i j}+e_{i j}
$$

where $\mu=$ overall mean response

$\alpha_{\mathbf{i}} \quad=$ effect of ith treatment

$\beta_{\mathbf{j}} \quad=$ effect of $\mathrm{jth}$ doe

$\alpha \beta_{\mathrm{ij}}=$ interaction between ith treatment and $\mathrm{jth}$ doe

$e_{i j}=$ effect of random error

The differences between treatments are calculated as the confidence intervals for the contrasts. Since the number of contrasts affects the level of significance, not all possible contrasts are included in the statistical analysis, but in some cases only those that are considered to be of interest. In such cases, the analysed contrasts are listed under each table and consequently no other statistical comparisons can be made between group averages than those mentioned.

\section{Results}

The results from the digestibility trials are presented in Table 2 . The restrictively fed rabbits in Expt. 1 had significantly higher digestibility coefficients in period 1, for all components except ADF, than those that were fed ad libitum. In period 2 there were no differences between the realimented and continuously ad libitum fed animals, but there were some significant differences between both those groups and the continuously restricted animals. In Expt. 2 the pattern was the same but the differences were smaller.

In period 1 the restrictively fed group obtained 73 p. 100 in Expt. 1 and 63 p. 100 in Expt. 2 of the average daily feed consumption of the ad libitum fed group (Table 3 ). The restrictive feeding caused significant inter-group differences in days in period and daily live weight gain. Table 4 presents growth and feed conversion during the realimentation period. There were no significant differences between the restricted-realimented group and the continuously ad libitum fed group in any of the parameters in the two experiments. However, there was a tendency that the previously restricted group in Expt. 1 had a higher feed consumption at ad libitum feeding during realimentation than the continuously ad libitum fed group and that the restricted-realimented animals had a lower feed consumption both in period 2 and totally and in both experiments compared with the continuously ad libitum fed animals.

The rabbits that were continuously restricted throughout their growth period obtained 65 p. 100 and 64 p. 100 of the average daily consumption of their litter mates during period 2 in Expt. 1 and Expt. 2 respectively. The continuously restricted rabbits had significantly lower daily weight gain and higher feed consumption than the other groups in both experiments. 


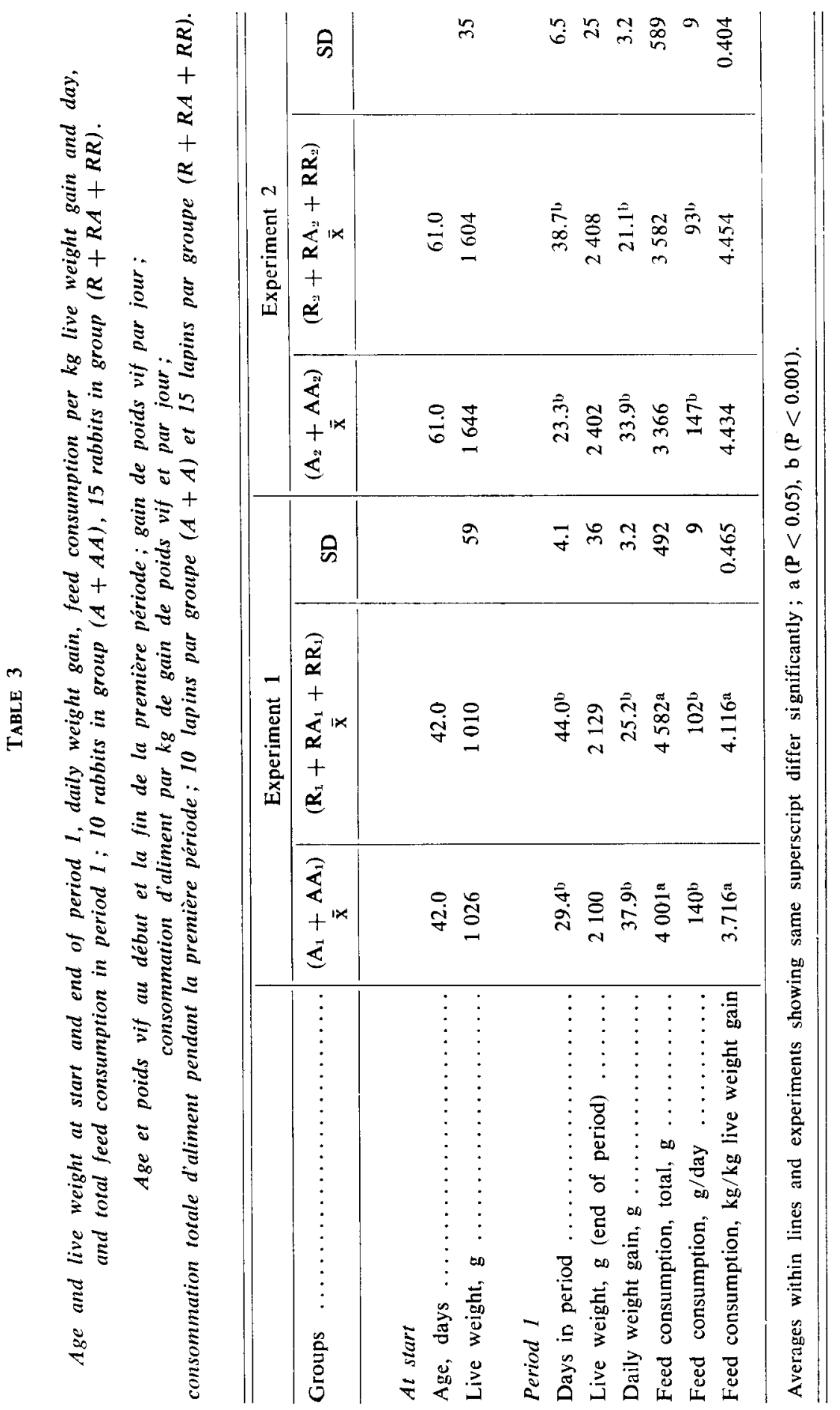




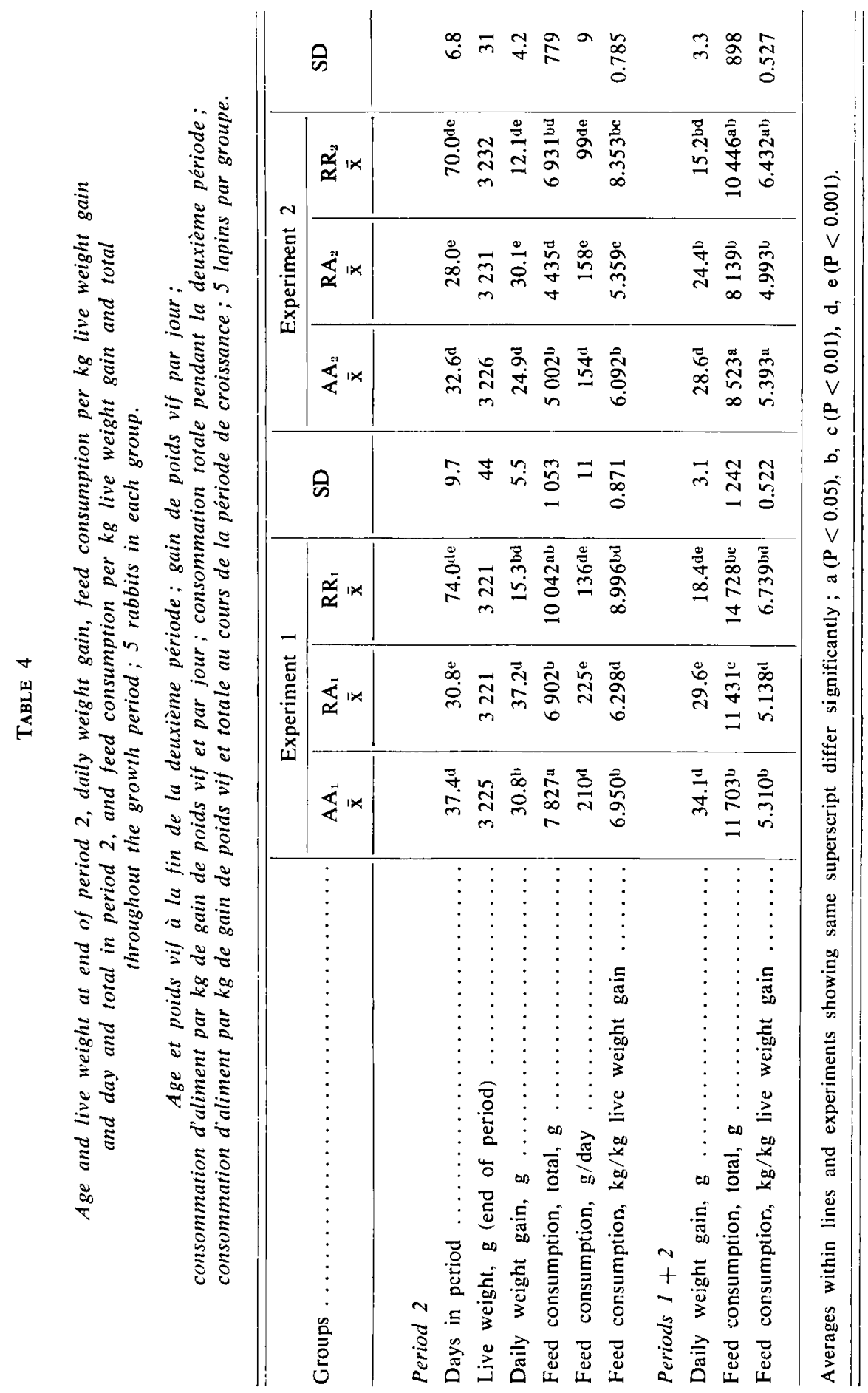


TABLE 5

Carcass characteristics and carcass composition; 5 rabbits in each group, Expt. 1.

Caractéristiques physiques des carcasses et composition corporelle; 5 lapins par groupe, expérience 1.

\begin{tabular}{|c|c|c|c|c|c|c|c|}
\hline Group & $\begin{array}{l}\mathrm{O}_{1} \\
\overline{\mathbf{x}}\end{array}$ & $\begin{array}{c}A_{1} \\
\overline{\mathbf{x}}\end{array}$ & $\begin{array}{c}\mathbf{R}_{1} \\
\overline{\mathbf{x}}\end{array}$ & $\begin{array}{l}\mathrm{AA}_{\mathrm{i}} \\
\overline{\mathrm{X}}\end{array}$ & $\begin{array}{c}\mathbf{R A}_{\mathbf{t}} \\
\overline{\mathbf{x}}\end{array}$ & $\begin{array}{c}\mathrm{RR}_{1} \\
\overline{\mathbf{x}}\end{array}$ & SD \\
\hline Empty body weight, g & 877 & 1843 & 1830 & 2871 & 2843 & 2835 & 438 \\
\hline Carcass weight, $\mathrm{g} \ldots \ldots$ & 426 & 1012 & 1013 & $1580^{\mathrm{f}}$ & $1597 \mathrm{~g}$ & $1728^{\mathrm{fg}}$ & 37 \\
\hline Dressing percentage, $\%$ & 43.1 & 48.1 & 47.2 & $49.9:$ & $49.9^{1}$ & $53.6^{\mathrm{al}}$ & 1.9 \\
\hline Dressed fat, g DM .... & 14.4 & $49.5^{n}$ & $22.0^{\mathrm{n}}$ & $129.6^{f}$ & $104.7^{b}$ & $76.0^{\text {be }}$ & 14.5 \\
\hline Bones, $\mathrm{g} \ldots \ldots \ldots$ & 64.2 & 110.6 & 107.3 & 134.4 & 141.9 & 152.8 & 11.3 \\
\hline \multirow{2}{*}{\multicolumn{8}{|c|}{$\begin{array}{l}\text { Soft tissue } \\
\text { Chemical composition }\end{array}$}} \\
\hline & & & & & & & \\
\hline $\mathrm{DM}, \% \ldots \ldots \ldots$ & 23.00 & 25.95 & 24.75 & $29.29^{\mathrm{cf}}$ & $27.19 \mathrm{c}$ & $26.11^{f}$ & 0.80 \\
\hline Crude protein, \% & 16.73 & $17.53^{\mathrm{a}}$ & $18.85 \mathbf{a}$ & 17.78 & $17.24^{\mathrm{c}}$ & $18.68^{\mathrm{c}}$ & 0.62 \\
\hline Ether extract, \% & 5.29 & $7.45^{f}$ & $4.85 \mathrm{f}$ & $10.61^{\text {af }}$ & $9.03^{\mathrm{ag}}$ & $6.52^{\mathrm{fg}}$ & 0.78 \\
\hline Ash, $\% \ldots \ldots$ & 0.97 & 0.97 & 1.04 & 0.92 & 0.91 & 0.91 & 0.23 \\
\hline Energy, $\mathrm{MJ} / \mathrm{g}$ soft tissue & 5.90 & $6.80^{\mathrm{c}}$ & $6.12^{c}$ & $7.98^{\mathrm{dff}}$ & $7.33^{\mathrm{de}}$ & $6.73^{\mathrm{ef}}$ & 0.25 \\
\hline
\end{tabular}

Averages within lines showing same superscript differ significantly; a, b(P<0.05), c, d, e $(P<0.01)$, $f, g(P<0.001)$. Contrasts in the statistical analysis; $\left(A_{1}-R_{1}\right),\left(A A_{1}-R A_{1}\right),\left(A A_{1}-R R_{1}\right),\left(R A_{1}-R R_{1}\right)$.

\section{TABLE 6}

Carcass characteristics and carcass composition; 5 rabbits in each group, Expt. 2.

Caractéristiques physiques des carcasses et composition corporelle;

5 lapins par groupe, expérience 2.

\begin{tabular}{|c|c|c|c|c|c|c|c|}
\hline Group & $\begin{array}{c}\mathrm{O}_{z} \\
\overline{\mathbf{x}}\end{array}$ & $\begin{array}{c}A_{x} \\
x\end{array}$ & $\begin{array}{l}R_{:} \\
\bar{x}\end{array}$ & $\underset{\overline{\mathbf{x}}}{\mathrm{AA}}$ & $\begin{array}{c}\mathrm{RA}_{3} \\
\overline{\mathbf{x}}\end{array}$ & $\begin{array}{c}\mathbf{R R}_{y} \\
\overline{\mathbf{x}}\end{array}$ & SD \\
\hline Empty body weight, g & 1423 & 2177 & 2173 & 2975 & 2958 & 2984 & 373 \\
\hline Carcass weight, $\mathrm{g} \ldots$ & 775 & 1258 & 1327 & 1725 & 1708 & 1736 & 44 \\
\hline Dressing percentage, \% & 49.6 & 52.6 & 54.9 & 53.8 & 52.8 & 53.7 & 1.6 \\
\hline Dressed fat, g DM .... & 34.0 & $73.5: 1$ & $45.3: 1$ & $129.5 d$ & $115.0^{c}$ & $67.4^{\mathrm{cd}}$ & 14.2 \\
\hline Bones, $\mathrm{g}$ & 89.6 & 130.5 & 137.9 & 154.9 & 153.4 & 162.0 & 9.1 \\
\hline \multirow{2}{*}{\multicolumn{8}{|c|}{$\begin{array}{l}\text { Soft tissue } \\
\text { Chemical composition }\end{array}$}} \\
\hline & & & & & & & \\
\hline $\mathrm{DM}, \%$ & 26.01 & 28.66 & 26.17 & $31.46^{11}$ & 28.69 & $25.10^{\mathrm{d}}$ & 2.06 \\
\hline Crude protein, \% & 17.79 & $18.02^{\mathrm{a}}$ & $19.02^{\prime \prime}$ & 18.21 & $17.95^{\mathrm{b}}$ & $18.94^{b}$ & 0.50 \\
\hline Ether extract, \% . & 7.11 & $9.62^{c}$ & $6.10^{\circ}$ & 12.26 ald & $9.79 a$ & $5.15^{\mathrm{de}}$ & 1.42 \\
\hline Ash, \% & 1.10 & 1.02 & 1.03 & 1.00 & 0.96 & 1.00 & 0.07 \\
\hline $\begin{array}{l}\text { Energy, } \mathrm{MJ} / \mathrm{kg} \text { soft tis- } \\
\text { sue } \ldots \ldots \ldots \ldots \ldots \ldots\end{array}$ & 6.76 & $7.74^{\mathrm{d}}$ & 6.674 & $8.74 \mathrm{e}$ & $7.74 \mathrm{e}$ & $6.31^{\mathrm{e}}$ & 0.53 \\
\hline
\end{tabular}

Averages within lines showing same superseript differ significantly; $a, b(P<0.05), c(P<0.01)$, d, e $(P<0.001)$. Contrasts in the statistical analysis ; $\left(A_{2}-R_{2}\right),\left(A_{2}-R A_{2}\right),\left(A_{2}-R R_{2}\right),\left(R_{2} R_{2} R_{2}\right)$. 
Carcass and dissection characteristics are presented in Tables 5 and 6 . There were no significant differences between groups in any of the experiments as regards empty body weight, carcass weight, dressing percentage, or weight of bones - with the exception of carcass weight and dressing percentage for the continuously restricted animals in Expt. 1. The amount of dressed fat, however, was significantly poorer for the continuously restrictively fed animals, than for those that were continuously fed ad libitum or restricted-realimented. The two last groups did not differ significantly from each other.

The chemical composition of the soft tissue differed quite widely between treatments in both experiments. At the end of period 1 the content of DM in the soft tissue was practically the same but the restrictively fed animals contained less fat and more protein than those that were ad libitum fed. At the end of period 2 the soft tissue of the realimented rabbits had a lower content of DM, the same content of protein and a lower content of fat than those that were continuously fed ad libitum. The soft tissue of the continuously restricted rabbits contained more protein and less fat than both the other groups. Table 7 shows a calculation of the composition of the soft tissue gain in different weight intervals. The soft tissue gain of the restricted-realimented rabbits had, during realimentation, a lower content of protein, the same content of fat and a higher content of water than the soft tissue gain of the continuously ad libitum fed animals.

The development of internal organs is presented in Table 8 . The liver was most affected by restriction and realimentation and this was especially noticeable in Expt. 1 . The dry weight of the liver increased by 25 p. 100 in animals continuously fed ad libitum in period 2, whereas it increased by almost 200 p. 100 in the realimented animals. When examining livers from Expt. 1, no significant differences were found between the realimented and continuously ad libitum fed animals as regards content of fat, protein and ash in the livers. The continuously restricted animals, however, had a higher content of protein in the liver tissue DM.

The fresh weight of the skin of the restricted-realimented and continuously restricted rabbits in Expt. 1 was significantly lower than that of the continuously ad libitum fed rabbits. However, in Expt. 2 there were no inter-group differences in fresh weight of the skins.

Carcass weight gain, feed efficiency and energy and protein retention are presented in Table 9. Total feed efficiency and energy retention were significantly poorer for the continuously restricted groups than for the restricted-realimented or continuously ad libitum fed groups. In Expt. 1 the restricted-realimented animals also had a poorer energy retention than the continuously ad libitum fed. No significant intergroup differences in protein retention were found in any of the experiments. 


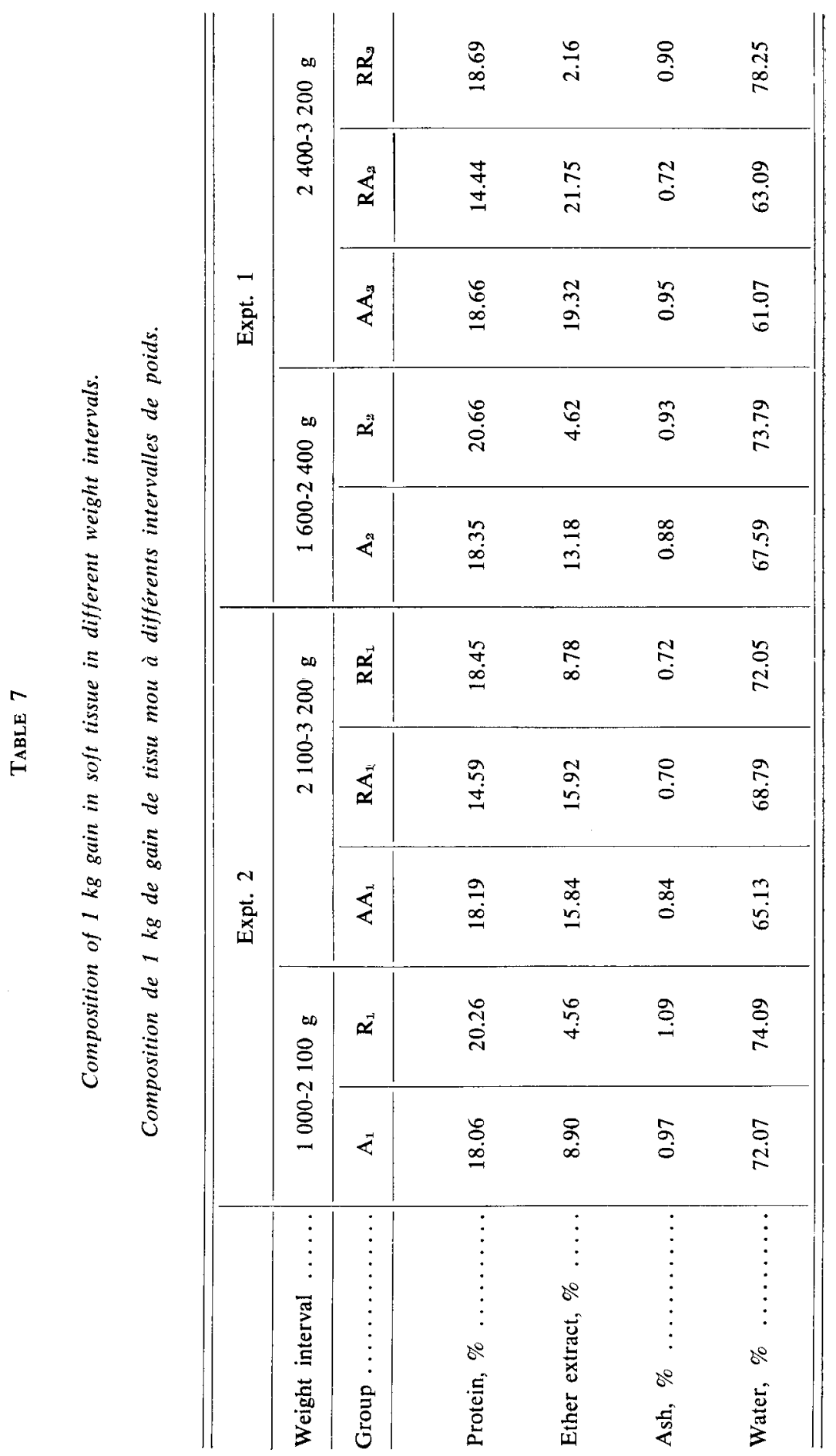


TABLE 8

Weight of dried internal organs (g); 5 rabbits in each group.

Poids des viscères secs $(g) ; 5$ lapins par groupe.

\begin{tabular}{|c|c|c|c|c|c|c|c|}
\hline & Stomach & $\begin{array}{c}\text { Small } \\
\text { intestine }\end{array}$ & Caecum & Colon & Liver & Heart & Kidneys \\
\hline \multicolumn{8}{|c|}{ Expt. 1} \\
\hline $\mathrm{O}_{1}$ & 2.69 & 4.94 & 1.65 & 1.85 & 10.26 & 0.47 & 1.68 \\
\hline$A_{1}$ & 5.12 & 10.48 & 4.58 & 5.25 & $22.80^{\mathrm{a}}$ & 0.99 & 3.25 \\
\hline $\mathbf{R}_{1}$ & 5.29 & 8.87 & 4.07 & 4.36 & $15.70^{\mathrm{a}}$ & 0.84 & 2.75 \\
\hline $\mathrm{AA}_{1}$ & 6.78 & 11.83 & 6.21 & 7.12 & $29.93^{\mathrm{cd}}$ & 1.37 & $3.99 a$ \\
\hline $\mathrm{RA}_{1}$ & 7.35 & $14.09^{a}$ & $6.89 a$ & $8.08^{c}$ & 41.19 te & $1.52^{\mathrm{c}}$ & $4.27^{c}$ \\
\hline $\mathrm{R}_{1}$ & 6.94 & $9.44^{a}$ & $5.84 a$ & $6.20^{c}$ & $22.09^{\mathrm{ce}}$ & $1.19^{\mathrm{c}}$ & $3.36^{\text {ac }}$ \\
\hline $\mathrm{SD}$ & 0.42 & 2.14 & 0.51 & 0.71 & 3.45 & 0.10 & 0.35 \\
\hline \multicolumn{8}{|c|}{ Expt. 2} \\
\hline $\mathrm{O}_{2}$ & 3.93 & 7.87 & 3,30 & 3.84 & 24.34 & 0.75 & 2.46 \\
\hline $\mathrm{A}_{2}$ & 4.67 & 8.01 & 4.67 & 5.05 & 24.45 & 1.17 & $3.39^{a}$ \\
\hline $\mathbf{R}_{2}$ & 5.04 & 7.02 & 4.75 & 4.68 & 21.28 & 1.07 & $2.83^{\mathrm{a}}$ \\
\hline $\mathrm{AA}_{2}$ & 5.21 & 9.12 & 5.75 & 6.36 & $28.46^{a}$ & 1.36 & $4.11^{b}$ \\
\hline $\mathrm{RA}_{\mathbf{2}}$ & 5.51 & 10.02 & 5.47 & $6.17^{\mathrm{a}}$ & $39.38^{\mathrm{ae}}$ & 1.40 & 3.64 \\
\hline $\mathrm{RR}_{\mathbf{2}}$ & 5.46 & 8.83 & 5.29 & $7.16^{\mathrm{a}}$ & $24.03^{c}$ & 1.39 & $3.58^{b}$ \\
\hline $\mathrm{SD}$ & 1.26 & 1.12 & 0.43 & 0.57 & 5.70 & 0.12 & 0.30 \\
\hline
\end{tabular}

Averages within columns and experiments showing same superscript differ significantly ; a, b $(P<0.05)$, c $(P<0.01)$, d, e $(P<0.001)$. Contrasts in the statistical analysis ; (A-R), (AA-RA), (AA-RR), (RA-RR). 


\section{TABLE 9}

Carcass weight gain ( $\mathrm{g} / \mathrm{day}$ ), $\mathrm{kg}$ feed per $\mathrm{kg}$ carcass weight gain and energy and protein efficiency; 5 rabbits in each group.

Gain de poids de carcasse ( $g$ par jour), consommation d'aliment ( $k g$ par $\mathrm{kg}$ de gain de carcasse) et rétention de l'énergie et de l'azote; 5 lapins par groupe.

\begin{tabular}{|c|c|c|c|c|}
\hline & $\begin{array}{l}\text { Carcass weight } \\
\text { gain, g/day }\end{array}$ & $\begin{array}{c}\mathrm{Kg} \text { feed } / \mathrm{kg} \\
\text { carcass weight } \\
\text { gain }\end{array}$ & $\begin{array}{c}\text { Retained } \\
\text { energy/gross } \\
\text { energy intake, \% }\end{array}$ & $\begin{array}{c}\text { Retained } \\
\text { protein/protein } \\
\text { intake, \% }\end{array}$ \\
\hline \multicolumn{5}{|l|}{ Expt. 1} \\
\hline \multicolumn{5}{|l|}{ Period 1} \\
\hline$A_{1} \ldots \ldots$ & $19.6^{\mathrm{a}}$ & 7.202 & $5.41^{\mathrm{c}}$ & 15.71 \\
\hline$R_{1} \ldots$ & $13.4 \mathrm{a}$ & 7.782 & $4.22^{c}$ & 16.34 \\
\hline SD $\ldots \ldots \ldots$ & 2.9 & 1.570 & 0.52 & 1.43 \\
\hline \multicolumn{5}{|l|}{ Period 2} \\
\hline $\mathrm{AA}_{1} \ldots \ldots \ldots$ & $15.6^{c}$ & 12.196 & $3.93 c$ & 8.51 \\
\hline $\mathrm{RA}_{1} \ldots \ldots \ldots$ & $20.1^{d}$ & 10.754 & $4.27 \mathrm{~d}$ & 8.00 \\
\hline $\mathbf{R R}_{1} \ldots \ldots \ldots$ & $10.0^{\mathrm{cd}}$ & 12.206 & $2.81^{\mathrm{cd}}$ & 8.23 \\
\hline SD $\ldots \ldots \ldots$ & 2.9 & 1.570 & 0.52 & 1.43 \\
\hline \multicolumn{5}{|l|}{ Periods $1+2$} \\
\hline $\mathrm{AA}_{1} \ldots \ldots \ldots$ & $17.7^{\mathrm{e}}$ & $10.195^{a}$ & $4.55^{\mathrm{ac}}$ & 11.25 \\
\hline $\mathbf{R A}_{1} \ldots \ldots \ldots$ & $15.6^{\mathrm{c}}$ & $9.882^{\mathrm{c}}$ & $3.97 \mathrm{ab}$ & 11.21 \\
\hline $\mathrm{RR}_{1} \ldots$ & $10.7^{c e}$ & $11.466^{\mathrm{ac}}$ & $3.23^{\text {he }}$ & 10.62 \\
\hline SD $\ldots$ & 1.6 & 0.973 & 0.47 & 1.45 \\
\hline \multicolumn{5}{|l|}{ Expt. 2} \\
\hline \multicolumn{5}{|l|}{ Period 1} \\
\hline $\mathbf{A}_{2} \ldots \ldots$ & $23.0^{\mathrm{a}}$ & 6.723 & $7.64^{\mathrm{c}}$ & 16.36 \\
\hline & $14.8^{\mathrm{a}}$ & 7.238 & $5.67 \mathrm{c}$ & 18.68 \\
\hline SD $\ldots \ldots \ldots$ & 3.6 & 1.901 & 0.91 & 2.67 \\
\hline \multicolumn{5}{|l|}{ Period 2} \\
\hline $\mathrm{AA}_{2} \ldots \ldots \ldots$ & $14.9^{\mathrm{c}}$ & $10.798^{\mathrm{e}}$ & $5.68^{\mathrm{e}}$ & 10.29 \\
\hline $\mathbf{R A}_{2} \ldots \ldots \ldots$ & $13.7^{\mathrm{a}}$ & $11.713^{c}$ & $5.48^{f}$ & 7.63 \\
\hline $\mathbf{R R}_{2} \ldots \ldots \ldots$ & $5.9 a c$ & $16.971^{\mathrm{ce}}$ & $1.76^{\mathrm{ef}}$ & 6.59 \\
\hline SD $\ldots \ldots \ldots \ldots$ & 3.6 & 1.901 & 0.91 & 2.67 \\
\hline \multicolumn{5}{|l|}{ Periods $1+2$} \\
\hline $\mathrm{AA}_{2} \ldots \ldots \ldots$ & $17.5^{\mathrm{a}}$ & 9.014 & $6.31^{\mathrm{e}}$ & 12.24 \\
\hline $\mathrm{RA}_{2} \ldots \ldots$ & 13.9 & 9.310 & $5.34^{\mathrm{f}}$ & 12.23 \\
\hline $\mathbf{R R}_{2} \ldots \ldots \ldots$ & $9.5^{\mathrm{a}}$ & 10.961 & $2.99 \mathrm{ef}$ & 10.69 \\
\hline SD $\ldots \ldots \ldots \ldots$ & 3.7 & 1.194 & 0.71 & 2.78 \\
\hline
\end{tabular}

Averages within columns experiments and periods showing same superscript differ significantly; a, b $(\mathbf{P}<0.05)$, c, d $(\mathrm{P}<0.01)$, e, f $(\mathrm{P}<0.001)$. 


\section{Discussion}

The digestibilty for energy in Diet 1 was on average 55 p. 100 , giving a value of about $9 \mathrm{MJ} \mathrm{DE} / \mathrm{kg}$ feed for the ad libitum fed animals (Table 2). The recommended values are 10.5 $\mathrm{MJ} \mathrm{DE} / \mathrm{kg}$ feed (NRC, 1977) at ad libitum feeding. The rabbits still managed to grow quite well on this diet. The restricted animals in Expt. 1 digested their feed considerably better than the ad libitum fed and realimented groups. These effects were not repeated in Expt. 2, where the diet had a better digestibility for energy, 62 p. 100 at ad libitum feeding, and the restricted feeding started at a higher age and weight. Thus it seems as if a restricted feed supply can be partly compensated for by a better utilization of the feed, especially if the diet is of a low nutritive value and possibly also if the restriction occurs early enough in life. Higher digestibility coefficients at low feeding levels have also been shown by Heli.berg (1949) and Lebas (1979).

In both experiments the rabbits showed some compensatory growth, measured as live weight gain, during realimentation. The higher live weight gain in the compensating animals was not significant in any of the experiments because of the small number of animals and the individual variation. A difference of more than 20 p. 100 in live weight gain between compensating and continuously ad libitum fed animals must be considered as important, however. When gut fill and changes in organ weights are considered and the weight gain measured as carcass weight gain (Table 8), there is still a 20 p. 100 difference between compensating and continuously ad libitum fed animals in Expt. 1 but none in Expt. 2. In the last experiment the carcasses of the restricted rabbits were slightly but not significantly heavier at the end of period 1 , than those that were continuously fed ad libitum, and the realimented animals were lighter than the latter group at the end of period 2. This made both the total carcass weight gain and daily carcass weight gain smaller for the realimented than for the continuously ad libitum fed animals, in spite of a shorter time in period 2 for the former group.

The rabbits in Expt. 1 that were fed ad libitum during realimentation showed a tendency to consume more feed per day than those that were fed ad libitum continuously. Experiments on other monogastrics (AUCKLAND, Morris \& Jennings, 1969; Auckland \& Morris, 1971 ; Ellis \& LaWrence, 1978 b) show the same pattern with the exception of those reported by MEYER \& Clawson (1964). Our rabbits had a remarkable ability to increase their daily feed consumption from one day to another by more than 100 p. 100 without any noticeable digestive problems.

Feed consumption per $\mathrm{kg}$ live weight gain was significantly greater for the restrictively fed rabbits during the restrictive period in Expt. 1. This is quite logical, considering the fact that the restrictively fed rabbits required feed for maintenance during a longer period of time. However, in Expt. 2 there was no difference in feed consumption per $\mathrm{kg}$ live weight gain between the restricted and ad libitum fed groups during period 1. During realimentation there was a tendency that the previously restricted animals had a lower feed consumption per kg live weight gain than the continuously ad libitum fed animals. Considering the entire growth period in the experiments, these small differences in feed consumption per $\mathrm{kg}$ live weight gain in the two periods tended to cancel each other out giving a feed consumption per $\mathrm{kg}$ live weight gain 
that was similar for the restricted-realimented and continuously ad libitum fed animals. The restriction thus did not cause any increase in total feed consumption to reach a certain slaughter weight, but only a delay in time.

There were no differences in empty body weight between groups in any of the experiments. Thus gut fill does not seem to be an important factor for the variation in dressing percentage. The continuously restricted animals in Expt. 1 had a greater carcass weight at the same live weight. Those animals had consistently, though not significantly (with the exception of the liver) smaller internal organs and significantly lower fresh weight of skin. In Expt. 2 internal organs and fresh weight of skin were less affected by restriction than in Expt. 1. This could possibly be due to the fact that the restrictive period started at a higher age and weight in Expt. 2. Lower fresh weight of skin after restrictive feeding in rabbits has also been found by LEBAS \& LAPLACE (1982).

The chemical analysis of the soft tissue showed that the composition of the gain was not the same in the different periods. It is shown in Table 7 that in period 1 in both experiments the soft tissue gain of the restrictively fed animals contained more protein and water and less fat than the soft tissue gain of those that were ad libitum. fed. In period 2, on the other hand, the soft tissue gain of the realimented animals contained less protein, more water and the same amount of fat. In both experiments it seems as if the animals were trying during realimentation to correct for the deviations from normal body composition caused by the restrictions. In all probability this would also have occurred, if the experiments had been prolonged.

The continuously restricted animals gained very little fat throughout the growth period in both experiments. This was also observed in rabbits by PARIGI-BINI et al. (1978), but low fat content after prolonged feed restriction is a general observation in many other species.

The liver changed dramatically in weight during realimentation. It is well known that the digestive tract and the liver, for example, can show a rapid and considerable variation in size due to actual functional demands (Goss, 1964, 1978). This has also been found in rabbits by Lebas \& LAPLACE (1974) and Lebas \& Laplace (1982). None of the other internal organs except kidneys in Expt. 2, differed significantly at the end of period 1 in any of the experiments. If the dry weight of all organs are added, however, the entire weight is smaller for the restricted animals than for those that were fed ad libitum. After realimentation the added weights are restored and even higher for the restricted-realimented animals. In Expt. 1 all organs are heavier, but in Expt. 2 only the liver. This suggests that if a restriction is followed by a higher - but still restricted - feeding level, priority is given to the development of the internal organs, especially the liver, and to the skin. Only if there is an excess of nutrients during the first part of the realimentation period is there a compensatory growth of other soft tissue. 


\section{Acknowledgements}

Financial support to the present study was given by the Swedish Council for Forestry and Agricultural Research.

\section{Résumé}

\section{Effets du rationnement et de l'alimentation ad libitum sur la croissance compensatrice et sur la composition corporelle du lapin}

Les effets du rationnement et de l'alimentation ad libitum sur la croissance et sur la composition corporelle du lapin ont été étudiés en deux expériences portant chacune sur 30 animaux. Dans la première, l'alimentation restreinte a été appliquée entre 1,0 et $2,1 \mathrm{~kg}$ de poids vif et dans la deuxième entre 1,6 et $2,4 \mathrm{~kg}$ de poids vif. Le rationnement a été fixé à 60 p. 100 de la consommation ad libitum des animaux de même portée ayant soit le même âge soit le même poids vif. La réalimentation a été pratiquée, ad libitum entre 2,1 et $3,2 \mathrm{~kg}$ de poids vif dans la première expérience et à $100 \mathrm{p} .100 \mathrm{de}$ la consommation ad libitum des animaux de même portée, au même poids vif, entre 2,4 et $3,2 \mathrm{~kg}$ de poids vif dans la deuxième expérience. Les lapins ont été abattus par groupes de 5 , chacun à un poids vif différent. Le premier abattage a été effectué au début de chaque expérience et le dernier au poids vif de $3,2 \mathrm{~kg}$.

La digestibilité apparente ainsi que la composition corporelle ont été étudiées

Les animaux rationnés ont présenté des carcasses moins grasses, avec le même contenu en eau et un contenu en protéines plus élevé que celles des animaux nourris ad libitum. La réalimentation des animaux préalablement soumis au rationnement a eu pour résultat l'obtention de carcasses ayant le même contenu en protéines, un contenu en eau plus élevé et un contenu lipidique encore moins important que celles des animaux nourris ad libitum.

Nous avons observé une tendance à une consommation plus élevée de la part des animaux réalimentés ad libitum, au cours de la période de post-rationnement dans la première expérience que celle des animaux nourris ad libitum, en continu. Le rationnement a eu un effet significatif sur la digestibilité apparente. Celle-ci a été plus importante chez les animaux rationnés et en particulier dans la première expérience.

Les traitements n'ont pas eu d'effets significatifs sur la consommation d'aliment, sur l'efficacité totale de l'aliment et sur l'utilisation de l'azote. Nous avons noté une tendance à ce que pendant la période de réalimentation, le gain de poids vif dans les deux expériences, et le gain de poids des carcasses dans la première expérience étaient plus importants qu'en alimentation ad libitum en continu, sans que les différences soient toutefois statistiquement significatives.

Le poids des foies a été influencé par le rationnement et par la réalimentation.

Mots clés : Lapin, rationnement, réalimentation, croissance compensatrice, composition.

Received in March 1983.

Accepted in August 1983.

\section{References}

Allee G.L., Noll M., 1980. Effects of restricted nutrient intake during the first three weeks of life on subsequent performance and carcass composition of pigs. J. Anim. Sci., 51, Suppl. 1, 182.

AuCKLand J.N., Morris T.R., Jennings R.C., 1969. Compensatory growth after undernutrition in market turkeys. Br. Poult. Sci., 10, 293-302. 
AUCKLAND J.N., Morris T.R., 1971. Compensatory growth after undernutrition in market turkeys : Effect of low protein feeding and realimentation on body composition. Br. Poult. Sci., 12, 137-150.

Deaton J.W, Reece F.N., Kubena L.F., Lott B.D., May J.D., 1973. The ability of the broiler chicken to compensate for early growth reduction. Poult. Sci., 52, 262-265.

Dunn O.J., Clarke V.A., 1974. Applied statistics, Wiley, New York, 387 p.

Ellis N.W., LaWrence T.L.J., 1978 a. Energy under-nutrition in the weanling filly foal. I. Effects on subsequent live-weight gains and onset of oestrus. Br. Vet. J., 134, 205-211,

Ellis N.W., LaWrence T.L.J., 1978 b. Energy under-nutrition in the weanling filly foal. III. Effects on heart rate and subsequent voluntary food intake. Br. Vet. J., 134, 333-341.

Goering H.K., Van Soest P.J., 1970. Forage fibre analysis, USDA Agric. Handbook, 379.

Goss R.J., 1964. Adaptive growth, 360 p. Academic Press Inc., London.

Goss R.J., 1978. The physiology of growth, 427 p. Academic Press Inc., London.

Harris P.M., Widdowson E.M., 1978. Deposition of fat in the body of rat during rehabilitation after early undernutrition. Br. J. Nutr., 39, 201-211.

Hellberg A., 1949. Metabolism of rabbits at different plans of nutrition, 184 p. Swedish Univ. of Agric. Sciences, Uppsala. Diss.

Lebas F., 1979. Efficacité de la digestion chez le lapin adulte. Effets du niveau d'alimentation et du stade de gestation. Ann. Biol. anim. Biochim. Biophys., 19, 969-973.

Lebas F., Laplace J.P., 1974. Mensurations viscérales chez le lapin. III. Variations chez la femelle au cours d'un cycle de reproduction en fonction du niveau d'alimentation durant la gestation. Ann. Zootech., 23, 267-292.

Lebas F., Laplace J.P., 1982. Mensurations viscérales chez le lapin. IV. Effets de divers modes de restriction alimentaire sur la croissance corporelle et viscérale. Ann. Zootech., 31, 391-430.

Liebert F., v. Lengerken G., Schröder Ch., Gebhardt G., Pfeiffer H., 1981. Nutzung kompensatorischer Wachstumseffekte bei Mastschweinen und deren Einfluss auf Körperzusammensetzung und Kenndaten der Schlachtkörperqualität. Tierzucht, 35, 367-370.

Liljedahl L.E., Neimann-Sørensen A., 1968. Body development, growth efficiency, fertility and milkproduction in relation to plane of nutrition during the rearing period as shown in studies of mice. Acta Agric. Scand., 18, 49-59.

Lister D., MCCanCE R.A., 1967. Severe undernutrition in growing and adult animals, 17. The ultimate results of rehabilitation : Pigs. Br. J. Nutr., 21, 789-799.

Mattsson P., 1978. Crude fat determinations in Feeding-Stuffs - some studies of extraction and hydrolysis methods, 19 p. Uppsala. Statens Lantbrukskemiska Laboratorium.

McMeekan C.P., 1940. Growth and development in the pig. With special reference to carcass quality characters. Part III. Effect of the plane of nutrition on the form and composition of the bacon pig. J. Agric. Sci., 30, 511-569.

Meyer J.H., Clawson W.J., 1964. Undernutrition and subsequent realimentation in rats and sheep. J. Anim. Sci., 23, 214-224.

NRC, 1977. Nutrient requirements of rabbits, 30 p. National Academy of Sciences, Washington D.C.

Ouhayoun J., Delmas D., Lebas F., 1979. Influence du taux protéique de la ration sur la composition corporelle du lapin. Ann. Zootech., 28, 453-458.

Parigi-Bini R., Dallerive V., Mazzarella M., 1978. Net energy requirements of growing rabbits. Arch. Geflügelk., 42, 59-62.

Pokniak J.A., CoRneJo S.B., 1982. Effects of energy and protein undernutrition on productive performance and carcass, liver and digestive tract composition of broiler males. Nutr. Rep. Int., 26, 319-327.

REID J.T., White O.D., 1977. The phenomenon of compensatory growth. Proc. Cornell Nutrition Conference, 16-27.

WILSON P.N., OSBOURN D.F., 1960. Compensatory growth after undernutrition in mammals and birds. Biol. Rev., 35, 324-363. 